\title{
Fibroblast Growth Factor 2 Increases Otx2 Expression in Precursor Cells from Mammalian Telencephalon
}

\author{
Laurence Robel, ${ }^{1, a}$ Min Ding, ${ }^{1}$ Alaina J. James, ${ }^{1, b}$ Xu Lin, ${ }^{1}$ Antonio Simeone, ${ }^{2}$ James F. Leckman, ${ }^{1}$ and Flora \\ M. Vaccarino \\ ${ }^{r}$ Child Study Center, Yale University, New Haven, Connecticut 06520 and ${ }^{2}$ International Institute of Genetics and \\ Biophysics, CNR, 80125 Naples, Italy
}

\begin{abstract}
Dissociated primary cultures from rat telencephalon at different developmental stages were used to study the effect of basic fibroblast growth factor (FGF2) on Otx2, DIx1, and $E m \times 1$, three homeobox genes expressed in different regions of the developing mammalian forebrain. At embryonic day (E)13.5, the regional pattern of expression of Otx1, Otx2, $D I \times 1, D I \times 2, D I \times 5$, and $E m \times 1$ is maintained in primary culture, suggesting that cells are already committed to a regional identity at this stage. In these cultures, Otx2 is expressed by precursor cells, whereas $D / x 1$ and $E m \times 1$ are predominantly expressed by postmitotic cells. We found that FGF2 increased Otx2 expression within precursor cells and the total number of Otx2-expressing cells. This effect was gene-specific, dose-dependent, and temporally regulated, with larger effects at earlier stages of development (E11.5). At E13.5, the effect of FGF2 on Otx2 expression was restricted to the basal telencephalon. Our results suggest that a restricted population of neuroblasts respond to FGF2 in a temporally regulated fashion by proliferating and increasing Otx2 expression. This interaction between FGF2 and Otx2 may be important for the regulation of neurogenesis in the forebrain.
\end{abstract}

[Key words: basic fibroblast growth factor (FGF2), Otx2, homeobox gene, rat, telenceptialon, cerebral cortex, basal ganglia, development, RNase protection assay, in situ hybridization, cell culture]

The development of a functional nervous system involves many steps, including the proliferation of precursor cells, their differentiation, their migration to appropriate locations and the establishment and maintenance of synaptic connections. These events are orchestrated by interactions between cell-intrinsic genetic information and a variety of environmental cues, such as secreted factors and cell-to-cell interactions (McConnell, 1991; CamposOrtega, 1993; Ghysen et al., 1993). Homeobox genes are a class of transcriptional regulators that are involved in the specification

\footnotetext{
Received Apr. 5, 1995; revised July 27, 1995; accepted Aug. 2, 1995.

This work was supported in part by NARSAD grants awarded to L.R., J.F.L., and F.M.V., grants from the Singer-Polignac and Philip Foundations to L.R. and a grant from the Italian Association of Cancer Research (AIRC) to A.S We thank T. Galli, K. Wikler, M. S. Schwartz, and F. Ruddle for critically reading an earlier version of the manuscript.

Correspondence should be addressed to Dr. Flora M. Vaccarino, Child Study Center, 230 South Frontage Road, New Haven, CT 06520.

"Present address: Centre Hospitalier Public de l'Enfant et de l'Adolescent Fondation Vallee, Gentilly, France.

'Present address: 2111 Holly Hall \#1615, Houston, TX 77054.

Copyright (C) 1995 Society for Neuroscience $0270-6474 / 95 / 157879-13 \$ 05.00 / 0$
}

of cell fate and pattern formation in the invertebrate CNS (McGinnis and Krumlauf, 1992). Mutational analyses suggest that homeobox genes play a similar role in the determination of cell identity within the vertebrate hindbrain (Chisaka and $\mathrm{Ca}$ pecchi, 1991; Chisaka et al., 1992; Dolle et al., 1993). The commitment of progenitor cells to specific fates would thus depend on the establishment of patterns of homeobox gene expression, stably propagated through all descendants in a lineage (Lawrence and Morata, 1994).

Whether homeobox genes can be induced or regulated by extracellular factors is unclear. In the hindbrain, the acquisition of segmental identity and homeobox gene expression seem independent of position in the neuroepithelium and of signals from the mesoderm (Guthrie and Lumsden, 1992; Guthrie et al., 1992), suggesting that hindbrain homeobox gene expression is cell autonomous and signals an irreversible change in cell fate. However, treatment with retinoic acid can modify both cell identity and homeobox gene expression in this brain region (Marshall et al., 1992; Kessel, 1993). Interactions between homeobox genes and secreted factors have been also shown to be important in the induction of mesoderm in Xenopus (Ruiz i Altaba and Melton, 1989; Cho and De Robertis, 1990; von Dassow et al., 1993) and the development of motor neurons in the spinal cord (Ericson et al., 1992). However, little is known concerning the interactions between these genes and extracellular cues in the development of the forebrain.

Members of the Otx, Emx, and $D l x$ families of homeobox genes, recently identified in the vertebrate forebrain, are homologs of homeobox genes expressed in the Drosophila head (Porteus et al., 1991; Price et al., 1991; Simeone et al., 1992a, 1993, 1994). The $D l x$ genes are primarily expressed in the basal telencephalon and diencephalon (Porteus et al., 1991; Price et al., 1991; Bulfone et al., 1993; Simeone et al., 1994), whereas the Emx genes are expressed in the dorsal telencephalon (Simeone et al., 1992b). Otx2 is expressed in the primitive head fold before the onset of neurogenesis in the mouse (E7.5) and defines the rostral fore-midbrain junction at E10; by E12.5-E13.5, Otx2 is downregulated in the dorsal telencephalon, persisting in the basal telencephalon until midneurogenesis (E15-E16) (Simeone et al., 1993; Frantz et al., 1994).

Members of the fibroblast growth factor (FGF) family specify cell fate and regulate morphogenesis in the mesoderm and in the limb through actions on homeobox gene expression (Ruiz i Altaba and Melton, 1989; Niswander and Martin, 1993). These factors are likely to affect the development of the forcbrain. Basic Fibroblast growth factor (FGF2) is expressed at early 
stages of neurogenesis in the developing mammalian forcbrain (Powell et al., 1991b; Giordano et al., 1992) where several high affinity FGF receptor types (FGFR-1, FGFR-2, and FGFR-3) are expressed in the proliferative ventricular zone (Heuer et al., 1990; Wanaka et al., 1991; Orr-Urtreger et al., 1991; Peters et al., 1993). This pattern is strikingly similar to the localization of Otx2, which is localized in the ventricular proliferative layer of the mesencephalon, diencephalon, and telencephalon (Sinteone et al., 1993; Frantz et al., 1994), and suggests that Otx2 may be expressed by progenitor cells receptive to FGF2. In vitro studies of the development of forebrain neurons have demonstrated that FGF2 increases neuroblast proliferation and differentiation (Gensburger et al., 1987; Murphy et al., 1990; Ray et al., 1994; Vaccarino et al., 1995), as well as neuronal survival (Walicke et al., 1986). Furthermore, it appears that the proliferative effect of FGF2 on neuroblasts is specific for the glutamate neuronal lineage, as demonstrated by antisense oligonucleotide mediated blockade of FGF2 expression (Vaccarino et al., 1995). Such effects may be mediated through an action of FGF2 on the expression of transcription factors contained in progenitor cells, including homeobox genes.

To test the hypothesis that FGF2 induces the expression of specific homeobox genes in precursor cells, we used primary cultures of cells from rat telencephalon treated with FGF2 at different developmental stages. In these cultures, the expression of homeobox genes of the Otx, Emx, and Dlx families in basal and dorsal telencephalon mirrors their regional pattern of expression in vivo. We report that Otx2 expression is specifically stimulated by $\mathrm{FGF} 2$ in precursor cells.

\section{Materials and Methods}

Animals. Rat embryos were obtained from timed-pregnant rats (Charles River, Raleigh, NC). The morning after a vaginal plug was detected was considered as embryonic day 0.5 (E0.5).

Primary cultures. Primary dissociated cultures were prepared from the neuroepithelium of embryonic day 11.5 (E11.5), 12.5 (E12.5), and 13.5 (E13.5) rat telencephalon. Cells were plated on polyornithine (15 $\mu \mathrm{g} / \mathrm{ml})$ and laminin $\left(2 \mu \mathrm{g} / \mathrm{cm}^{2}\right)$ pretreated wells, at a density of $15 \times$ $10^{4}$ cells per $\mathrm{cm}^{2}$, as previously described (Vaccarino et al., 1995). During the first $2 \mathrm{hr}$ after plating, the medium was supplemented with $10 \%$ fetal bovine serum (FBS). Cells were then maintained in serum free medium (SFM) $(50 \%$ DMEM $/ 50 \%$ F 12, $50 \mathrm{IU} / \mathrm{ml}$ of penicillin, $50 \mu \mathrm{g} /$ $\mathrm{ml}$ of streptomycin, $2 \mathrm{mM}$ glutamine, $0.110 \mathrm{mg} / \mathrm{ml}$ sodium pyruvate, 25 mM HEPES, $100 \mu \mathrm{g} / \mathrm{ml}$ transferrin, $5 \mu \mathrm{g} / \mathrm{ml}$ insulin, $20 \mathrm{nM}$ progesterone, 30 nм sodium selenite, and $60 \mu \mathrm{M}$ pulrescine). Cells were trealed with growth factors (FGF2: R\&D Systems, Minneapolis, MN; NGF: Boehringer Mannheim, Indianapolis, IN) at $3 \mathrm{hr}$ and at $2 \mathrm{~d}$ in vitro unless otherwise indicated. Cells were fed every $3 \mathrm{~d}$ by replacing $1 / 3$ of the medium with fresh SFM.

RNA extraction. Total RNA was isolated by homogenization in a guanidium isothiocyanate lysis buffer $\left(1 \mathrm{ml} / 2 \times 10^{6}\right.$ cells $)$ according to the one step procedure (Ausubel et al., 1989). RNA samples were resuspended in diethylpyrocarbonate (DEPC)-treated $\mathrm{H}_{2} \mathrm{O}$ and kept frozen at $-80^{\circ} \mathrm{C}$.

cDNA cloning. Polyadenylated RNA $\left[\right.$ poly $\left.\left(\mathrm{A}^{+}\right)\right]$was isolated from E12.5 rat telencephalon using the paramagnetic streptavidin beads (PolyATract, Promega, Madison, WI) according to the manufacturer's protocol. cDNA was prepared from $2 \mu \mathrm{g}$ of poly $\left(\mathrm{A}^{+}\right) \mathrm{RNA}$ using the AMV reverse transcriptase (Boehringer) in the presence of an oligo $d(T)$ primer according to standard methods (Ausubel et al., 1989). PCR was performed with Taq polymerase (Boehringer, Indianapolis, IN) using rat telencephalon cDNA as a template. PCR amplification was conducted in a standard buffer (Boehringer) supplemented with $4 \%$ formamide in the presence of 150 pmol of primers, as follows: Otxl: 35 amplification cycles, each cycle consisting of $30 \mathrm{sec}$ at $94^{\circ} \mathrm{C}, 45^{\circ} \mathrm{C}$, and $72^{\circ} \mathrm{C}$. Ot $x 2$ : 30 cycles, each cycle consisting of $1 \mathrm{~min}$ at $94^{\circ} \mathrm{C}, 2 \mathrm{~min}$ at $50^{\circ} \mathrm{C}$ and 3 min at $72^{\circ} \mathrm{C} ; E m \times 1: 30$ cycles, each cycle consisting of 1 min at $94^{\circ} \mathrm{C}$, $2 \mathrm{~min}$ at $60^{\circ} \mathrm{C}$, and $3 \mathrm{~min}$ at $72^{\circ} \mathrm{C} ; D l x I$ and $D l \times 2: 35$ cycles, each cycle consisting of $30 \mathrm{sec}$ each at $94^{\circ} \mathrm{C}, 45^{\circ} \mathrm{C}$, and $72^{\circ} \mathrm{C}$. Dlx 5 : 35 cycles, each cycle consisting of $30 \mathrm{sec}$ at $94^{\circ} \mathrm{C}, 56^{\circ} \mathrm{C}$, and $72^{\circ} \mathrm{C}$. The PCR products were analyzed on an agarose gel, purified with Geneclean (American Bioanalytical, Natick, MA) and directly sequenced using the cyclo-scquencing method (Stratagene, La Jolla, CA). The PCR products were then subcloned in the pCRTM II vector (TA cloning kit, Invitrogen, San Diego, CA) and their sequences confirmed (Sequenase version 2.0 kit, USB, Cleveland, $\mathrm{OH}$ ). Quiagen Plasmid maxikit (Quiagen, Chatsworth, CA) were used for maxipreps.

Ribonuclease protection (RNase) assay. High specific activity (2-5 $\times 10^{8} \mathrm{cpm} / \mu \mathrm{g}$ of RNA) antisense RNA probes were obtained from linearized rat cDNA templates (Fig. 1) by SP6- or T7-primed transcription using limiting concentration $(8 \mu \mathrm{M})$ of ${ }^{32} \mathrm{P}-\mathrm{UTP}$ (Amersham, Arlington Heights, IL). A low specific activity $\left(1-3 \times 10^{7} \mathrm{cpm} / \mu \mathrm{g}\right.$ of RNA) antisense probe, to be used as a control for RNA loading, was obtained by T7-primed transcription from the glyceraldehyde-phosphate-dehydrogenase (GAPDH) rat cDNA (pTRI-GAPDH, Ambion, Austin, TX), linearized by DdeI. Prior to hybridization, the probes were purified on a $6 \%$ denaturing polyacrylamide gel. RNase protection assays were conducted according to the manufacturer's protocol (RPA II kit; Ambion, Austin, TX), utilizing 5-20 $\mu \mathrm{g}$ of total RNA and 50,000 $\mathrm{cpm}$ of each probe in a $10 \mu \mathrm{l}$ hybridization volume. Probes obtained by SP6- and T7-primed transcriptions were hybridized independently to separate aliquots of the mRNA samples. After an overnight hybridization at $45^{\circ} \mathrm{C}$, samples were digested with a mixture of RNase A and T1 (1/100 dilution) for 30 minutes. Protected hybrids were analyzed by $6 \%$ polyacrylamide-urea gels, visualized on autoradiograms after an overnight exposure, and quantified by densitometry (see below). The sensitivity and the linearity of the assay was checked by hybridizing the antisense probes to known amounts of their respective sense transeripts and the GAPDH probe to known amounts of total RNA. The assay was linear between 5 and $20 \mu \mathrm{g}$ of total RNA, and between 0.5 and $5 \mathrm{pg}$ of Otxl, Otx2, Emx 1, Dlx1, Dlx2, and Dlx 5 mRNA.

Data analysis of RNase protection experiments. Quantification of all bands was carried out by scanning the autoradiograms with a densitometer (Visage 2000, Bioimage, Ann Arbor, MI). For all bands, the quantification was obtained after subtraction of the background of each lane. The boundaries of the bands were automatically detected by the computerized system and the quantification was obtained by the integration of the optic density within this boundary. To calculate the fold stimulation of $\mathrm{mRN} \wedge$ expression, the integrated optic density value of each band was normalized to the corresponding value of GAPDH; since the GAPDH signal appeared as a double band, values for both GAPDH bands were used in this calculation.

In situ hybridization. In situ hybridization experiments were carried out as described previously (Wahle and Beckh, 1992) with modifications. Digoxigenin-labeled sense or antisense RNA probes were synthesized from the homeobox rat cDNA templates (Fig. 1) by T7- or SP6primed in vitro transcription (SP6 and T7 megascript, Ambion) using digoxigenin-UTP (dig-UTP, Boehringer) as the labeling nucleotide (UTP/dig-UTP: $1.65 \mathrm{~mm} / 5 \mathrm{~mm}$ ). Cell monolayers growing on Lab-Tek tissue culture plates (Nunc) were fixed with $4 \%$ paraformaldehyde,

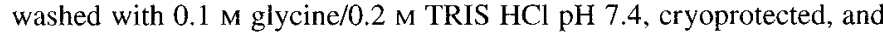
kept frozen $\left(-80^{\circ} \mathrm{C}\right)$ until use. Probes $(10 \mathrm{ng} / \mu \mathrm{l})$ were hybridized overnight at $55^{\circ} \mathrm{C}$ to cell monolayers previously permeabilized with $0.2 \mathrm{~N}$ $\mathrm{HCl}$ for $30 \mathrm{~min}$ at room temperature. Nonhybridized probes were degraded with RNase A $(50 \mu \mathrm{g} / \mathrm{ml})$ at $37^{\circ} \mathrm{C}$ for $20 \mathrm{~min}$. Slides were then washed with $50 \%$ formamide $/ 2 \times \mathrm{SSC}$ at $55-60^{\circ} \mathrm{C}$ and $0.1 \times \mathrm{SSC}$ at $55^{\circ} \mathrm{C}$ for $30 \mathrm{~min}$ each, rinsed three times with PBS, and subjected to immunocytochemistry (see below). After immunocytochemistry, slides were incubated for $2 \mathrm{hr}$ at room temperature with an alkaline phosphatase-coupled anti-digoxigenin antibody (1:500, Boehringer). Hybridized probes were then detected by incubation with the substrates 4-nitrobluetetrazolium chloride and 5-bromo-4-chloro-3 indolyl phosphate (Boehringer) for 12-16 hr. For each probe, several controls were carried out, including hybridization with a sense transcript, omission of probe, and omission of anti-digoxigenin antibody. These control conditions yielded background signal.

5-Bromo-2'-deoxyuridine (BrdU) labeling. Cell monolayers were treated for $1 \mathrm{hr}$ or $18-24 \mathrm{hr}$ at $37^{\circ} \mathrm{C}$ with a solution containing $\mathrm{BrdU}$ and fluorodeoxyuridine (cell labeling reagent, Amersham, 1:1000 and $1: 5000$, respectively) and fixed with $4 \%$ paraformaldehyde at the end of BrdU incorporation. Cultures were then processed for BrdU immunocytochemistry (see below), using an anti-BrdU monoclonal antibody (Amersham)

Immunocytochemistry was performed as previously described (Vac- 


\begin{abstract}
A. RAT EMX1 PROBE
1 gtgcatgtgcctggctgogctggatgcacaccccgccggcggcagcgc 48 cggggcaccgagcgttccccagagccccactacctcactcctcttcg 95 gcggcagcgac ATG TTC CAG CCC GCG ACT AAG CGG GGT 133 TTC ACC ATA GAG TCC TTG GTA GCC AAG GAT GGT GGC 169 ACC GGC GGG AGT CCT GGC AGC GGG GGC GCG GGC TCC 205 CAT CCC CTG GCT GTG GCC GCC TCA GAA GAA CGC TCA

241 GGC CCA CGG CGC TCA ACT ACC CTC ACC CCA GTG CAG 277 CCG AGG CGG CCT TCG TGA GTG GCT T
\end{abstract}

\section{B. RAT OTX2 PROBE}

1 CC ATG ACC TAT ACT CAG GCT TCA GGT TAT AGI CAA 36 GGC TAT GCT GGC TCG ACT TCC TAC TTT GGG GGC ATG 73 GAC TGT GGA TCT TAC TTG ACC CCT ATG CAT CAC CAG 110 CTT CCT GGA CCA GGG GCC ACA CTC AGT CCC ATG GGT 147 ACC AAT GCT GTT ACC AGT CAC CTC AAT CAG TCC CCA 180 GCT TCT CTT TCC ACC CAG GGA TAT GGA GCT TC

\section{RAT DLXI PROBE}

1 AAG CTG ATG AAG CAA GGC GGG GCA GCT CTG GAG GGC 37 ACC GCG CTG GCG AAT GGC AGG GCC TTG TCT GCC GGC

73 TCC CCA CCG GTA CCA CCC GGC TGG AAT CGA ATT CCT 109 CCT CTG GGA AGG GCT CAG GAG GAA A

\section{D.RAT OTX1 PROBE}

1 ATC TGG AGC CCG GCC TCC ATC TCT CCC GGC TCA GCG 37 CCG GCA TCC GTA TCA GTG CCA GAG CCA TTA GGC GCT 73 CCG AGC AAC GCC TCA TGC ATG CAG CGC TCG GTA GCC 109 GCA GGT GCG GCC ACT GCC GCG GCC TCC TAC CCT ATG 145 TCC TAT GGC CAG GGC GGA AGC TAT GGC CAG GGC TAC 181 CCC GCG CCT TCC TCT TCT TAC TTT GGC GGT GTA GAC 217 TGC AGC TCC TAC CTT GCG CCC ATG CAC TCT CAT CAC 253 CAC CCG CAC CAG CTT AGC CCC ATG GCA CCC TCC TCC 289 ATG GCT GGC CAC CAC CAC CAC CAC CCG CAC GCG CAC 325 CAC CCA CTG AGC CAA TCT TCA GGC CAC CAC CAC CAC 361 CAC CAT CAC CAC CAC CAC CAC CAA GGT TAT GGA GGC 397 TCT GGG CTC GCC TTC AAC TCT GCC GAC TGC TTG GAT 433 TAC AAG GAG CCC

\section{E. RAT DLX5 PROBE}

1 acagccatgtctgcttagaccagagcagctccaattctggcagcagc 47 ggccgcctcaataggacagccaccgccegggagctATGACAGGA 92 GTG TTT GAC AGA AGA GTC CAA GCA TCG ATC CGG CGA 128 CTT CCA AGC TCC GTT CCC GAC GTC CGC CGC CAT GCA 164 CCA CCC GTC TCA GGA ATC GCC AAC TTT GCC GGA GTC CTC GGC CAC CGA TTC TGA CTA CTA CAG TCC CGC GGG GGC CGC CCC TCA TGG CTA CTG CTC TCC TAC CTC TGC TTC TTA CGC AAA GCG CTC AAC CCA TAC CAG TAT CAG IAT CAC GGC GTG AA

\section{F.RAT DLX2 PROBE}

1 TCC ACG GCT ACG GAC AGC AGC TAC TAC ACC AAC CAG 37 CAG CAC CCG GCG GGT GGC GGC GGC GGG GGG GCC TCG 73 CCC TAC GCG CAC ATG GGC TCC TAC CAG TAC CAC GCC 109 AGC GGC CTC AAC AAC GTC TCC TAC TCC GCC AAA AGC 145 AGC TAC GAC CTG GGC TAC ACC GCC GCG TAC AC'I' I'CC 181 TAC GCG CCC TAC GGA ACC AGT TCG TCC CCA GTC AAC 217 AAC GAG CCC GAC AAG GAA GAC CTT GAG CCT GAA AT

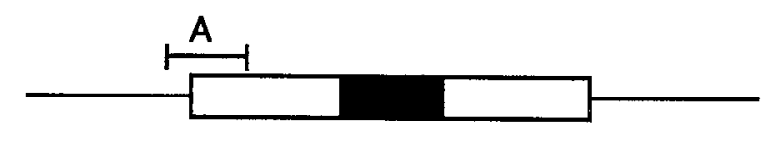

Homeobox
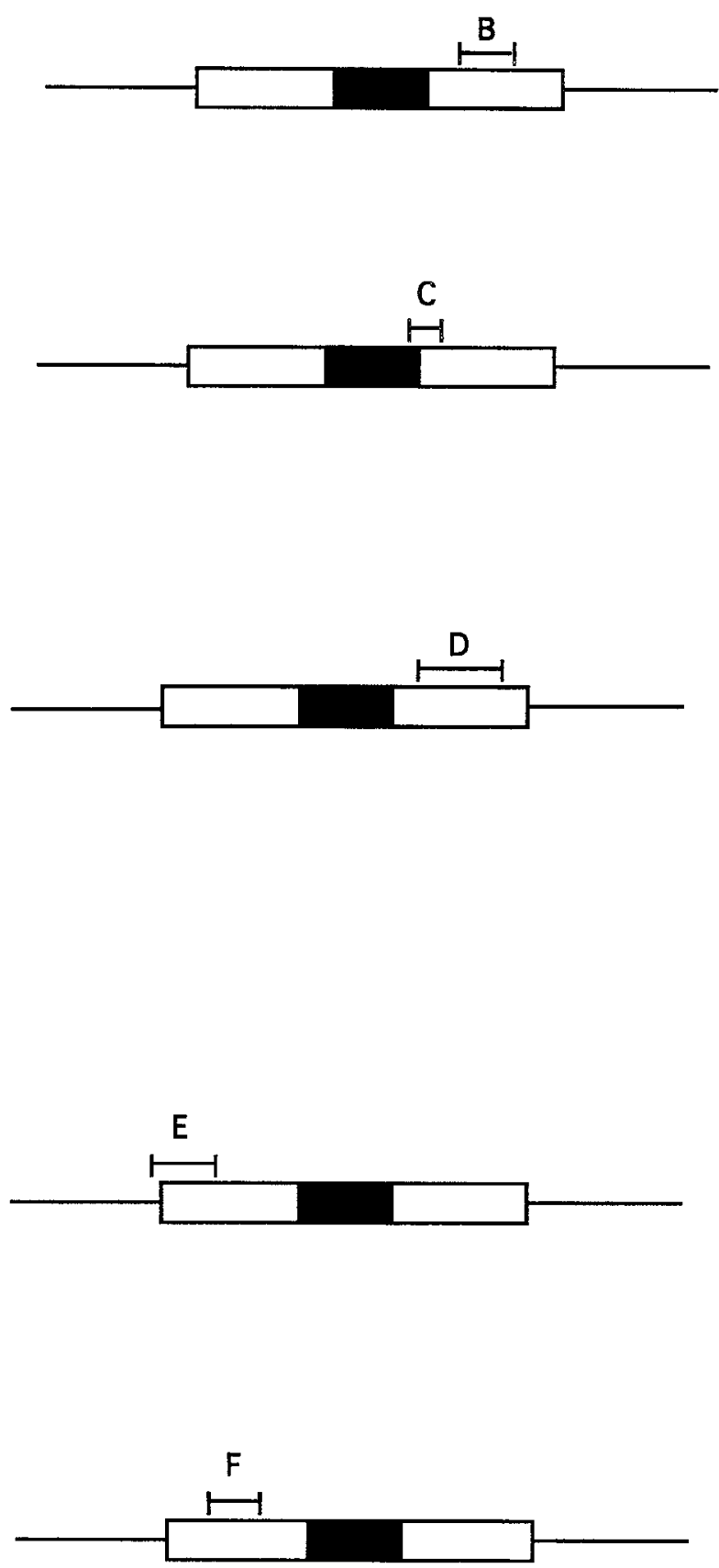

Figure 1. RNase assay protection and in situ hybridization probes for the rat Emxl, Otx2, Dlx1, Otxl, Dlx2, and Dlx5 genes (marked with brackets). The underlined nucleotides represent the primers used for PCR amplification. 
A

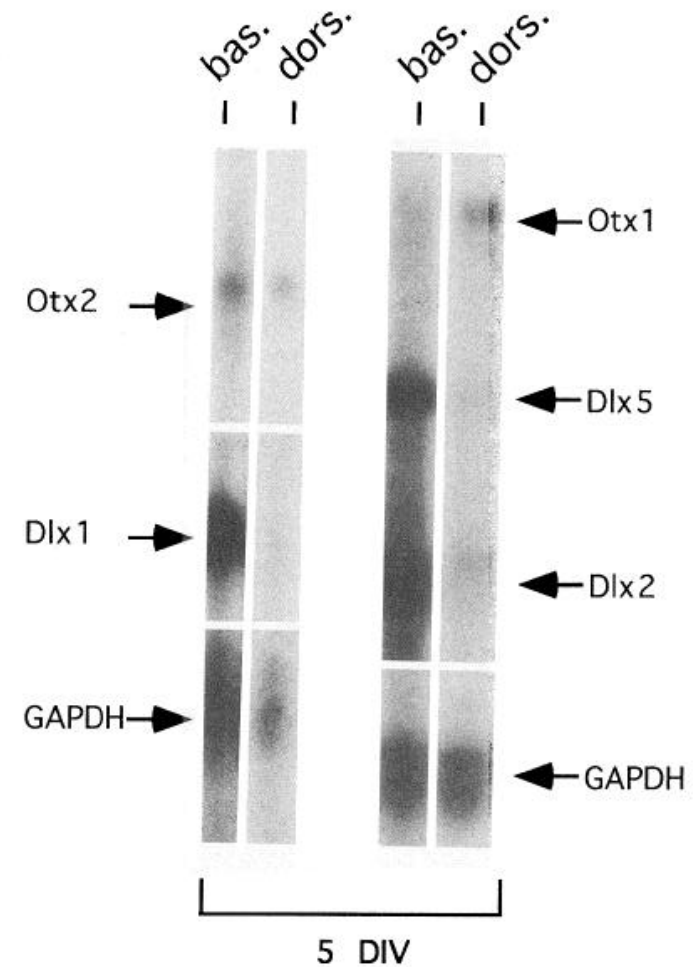

B

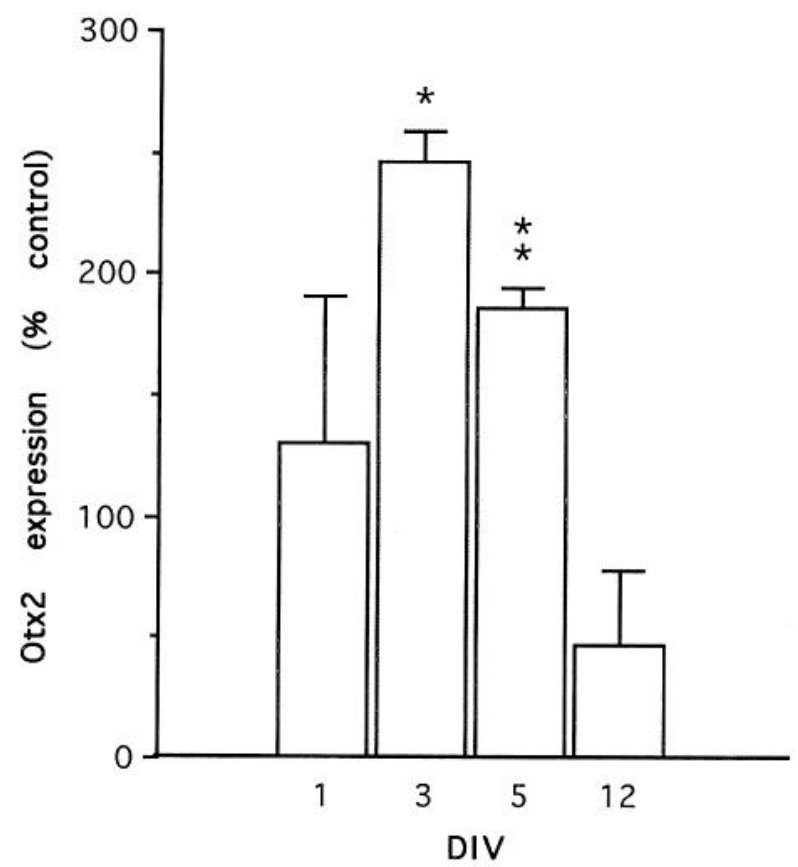

Figure 2. A, Expression of homeobox genes in primary cultures of basal and dorsal telencephalon. Messenger RNA levels of $O t x 2, D l x 1$, Otx $1, D l \times 2$, and $D l x 5$ were quantified by RNase protection assay in primary cultures of basal or dorsal telencephalon from E13.5 rat embryos, harvested at 5 DIV. Dlx $1, D l \times 2$ and $D l x 5$ are restricted to cultures of basal telencephalon, $O t x I$ is mainly expressed by cultures of dorsal telencephalon, and $O t x 2$ is expressed by both. B, Treatment with FGF2 increases the expression of $O t x 2$ at 3 and 5 DIV. Primary cultures of cells from E12.5 and E13.5 rat telencephalon were treated with FGF2 $(10 \mathrm{ng} / \mathrm{ml})$ at $2 \mathrm{hr}$ and, when appropriate, $2 \mathrm{~d}$ after plating and harvested carino et al., 1987, 1995). Primary antibodies directed against MAP2 (clone AP20, 1:5000, Boehringer), MAP1B (1:400, Amersham), and nestin (Rat 401, a gift of S. Hockfield, Yale University) were reacted to cell monolayers for $1 \mathrm{hr}$ at room temperature. Samples were incubated with a biotinylated secondary antibody for $1 \mathrm{hr}$ (1:200, Vector), and finally reacted with avidin-FITC $(2.5 \mu \mathrm{g} / \mathrm{ml}$, Vector $)$.

Data analysis for immunocytochemistry and in situ hybridization experiments. Cells considered as positive by in situ hybridization showed an intense, homogenous purple staining of the cell cytosol under bright field. Immunoreactive cells showed intense fluorescence in the cytoplasm and processes, or, in the case of BrdU, in the nucleus. Unstained cells were counted under DIC. In double labeling experiments, the number of single and double stained cells was counted by viewing the same field first under bright field and then under fluorescence. Sixteen random fields per culture were counted using a calibrated microscope reticule at a magnification of $100 \times$. Averages from three to six cultures were subjected to statistical analysis. Analysis of the reliability of cell counts between investigators on the same samples yielded $<10 \%$ variation.

\section{Results}

Isolation of the partial rat cDNAs for Dlx 1, Dlx2, Dlx5, Emx1, Otx1, and Otx2

In order to obtain species-specific probes for hybridization studies in rat tissue, we isolated partial cDNAs for several homeobox genes. Specific primers for Dlx1, Dlx2, Dlx5, Otx1, Otx2, and Emxl were designed in order to amplify 100-500 nucleotidelong sequences located outside of the homeobox domain. Whenever possible, PCR primers were complementary to regions of highest sequence homology between mouse and human genes. The sequences of the rat homeobox cDNAs were determined (Fig. 1) and compared with their human and mouse homologs. The 444-nucleotide-long sequence of rat Otxl was $88.8 \%$ and $94.8 \%$ homologous to the human and the mouse sequence, respectively. The 211-nucleotide-long sequence of rat Otx2 was $98 \%$ homologous to the mouse sequence, and $92 \%$ to the human sequence. Mouse and rat $D l x l$ sequences (133 nucleotides) were $92 \%$ homologous, and mouse and rat Dlx2 sequences $(251 \mathrm{nu}-$ cleotides) were $96.6 \%$ homologous. The sequence of rat Dlx5 (321 nucleotides) was $84.7 \%$ homologous to the human sequence. The human and rat EmxI sequences had slightly lower homology $(86 \%)$, probably because the amplified fragment contained a 105 nucleotide-long 5 ' untranslated sequence. These rat cDNAs were the templates for the synthesis of the RNA probes used in RNase protection assays and in situ hybridizations. When antisense probes were hybridized to total RNA extracted from tissue or primary cell cultures, protected hybrids migrated as single bands of the expected size (Fig. 2A). The GAPDH probe, an ubiquitously expressed gene which was used as a marker for total RNA, appeared as a double band of 80 nucleotides.

Telencephalic cells maintain in primary culture the regional pattern of expression of homeobox genes observed in vivo

In vivo, Dlx1, Dlx2, and Dlx5 are restricted to the basal telencephalon and diencephalon, Emxl to the dorsal telencephalon and $O t x 1$ and $O t x 2$ are expressed throughout the entire forebrain (Price et al., 1991; Simeone et al., 1992a,b, 1993, 1994; Bulfone et al., 1993; Frantz et al., 1994). The pattern of expression of

at $1,3,5$, and 12 DIV. Otx 2 expression was measured by RNase protection assay and quantified by densitometry. Results are normalized by the level of GAPDH and expressed as a percentage of control. Mean and SEMs were obtained from two to three independent experiments. *, $p<0.05$; **: $p<0.02$ (Student's $t$ test). 
these homeobox gencs was investigated in primary cultures of cells taken from basal and dorsal telencephalon (Fig. 2A). Otx1 and $O t \times 2$ were expressed in cultures from both dorsal and basal telencephalon. $D l x l, D l x 2$, and $D l x 5$ were highly expressed in cultures from the basal telencephalon and only trace amounts could be detected in cultures of dorsal telencephalon. Emxl was expressed in cultures from dorsal telencephalon and was never detected in basal telencephalic cells. Identical patterns were observed in four independent experiments. Thus, the expression of homeobox genes in primary cell cultures from basal and dorsal telencephalon is similar to the regional expression of homeobox genes observed in rat and mouse forebrain in vivo.

Otx2 is expressed in a subpopulation of nestin-positive precursor cells

To study the specific cellular localization of homeobox genes, in situ hybridization for $O t x 2, D l x I$ and $E m x I$ was coupled to immunostaining for different cell types in primary culture. Mature, postmitotic neurons were labeled by a MAP2 monoclonal antibody specific for the MAP2 high molecular weight isoforms (Binder et al., 1986). Precursor cells were identified by immunostaining for nestin, a cytoskeletal protein expressed by CNS stem cells (Lendahl et al., 1990). Proliferating precursor cells were also labeled by means of incorporation of 5-bromo- $2^{\prime}$ deoxyuridine (BrdU) during $S$ phase. We have previously determined that BrdU is incorporated by nestin-positive cells, but not by MAP2-positive neurons (F. M. Vaccarino, unpublished data). Otx2 mRNA is not present in terminally differentiated, MAP2positive neurons. Instead, Otx2-positive cells contain nestin immunoreactivity in cultures of E11.5 (Fig. 3), E12.5 and E13.5 telencephalon (Fig. 4), suggesting that Otx 2 is expressed by precursor cells. Furthermore, $12.3 \%$ (SEM $=6.4$ ) of the Otx2-containing cells incorporate BrdU during a $1 \mathrm{hr}$ BrdU pulse, suggesting that $0 t x 2$ is expressed by a proliferative population. To determine whether $0 t x 2$ expression is restricted to proliferating cells, cells were exposed to BrdU for a time longer than the length of a full cell cycle (Takahashi et al., 1994), to allow virtually all proliferative cells to "enter $\mathrm{S}$ phase and incorporate BrdU. After an 18-24 hr BrdU pulse, the percent of the Otx2containing cells which incorporate BrdU is $50.6 \%$ (SEM $=4.4$ ). These data suggest that $\operatorname{Otx} 2$, besides being expressed by proliferative cells, may be also transiently expressed by cells that have exited the cell cycle, although they are not mature enough to express MAP2. Alternatively, it is possible that some of the Otx2 positive cells which do not incorporate BrdU are relatively quiescent (have a longer cell cycle).

It is remarkable that only a subset of nestin-positive cells (approximately $20 \%$ under basal conditions) express Otx2 (Figs. 3, 4, Table 1). These data suggest that, in primary cultures of E11.5-E13.5 embryos, Otx2 mRNA is expressed by a subpopulation of precursor cells.

In contrast to $O t \times 2$, the great majority of cells expressing $D l x I$ are postmitotic neuronal cells. Specifically, 85.2\% (SEM = $3.9 \%$ ) of $D l x 1$-expressing cells are MAP1B-positive immature neurons, and $30.2 \%(\mathrm{SEM}=8.3 \%)$ of $D l x 1$-expressing cells are MAP2-positive neurons. A subset of $D l x l$-expressing cells are proliferative cells since they incorporate BrdU $(23.2 \%, \mathrm{SEM}=$ $6.0 \%)$.

FGF2 treatment increases the expression of Otx 2 in a specific and dose dependent fashion

FGF2 treatment of primary cultures derived from E1 1.5-E13.5 rat telencephalon increases cell proliferation. This increased pro- lifcration is detected as early as $1 \mathrm{~d}$ after FGF2 treatment and persists for several days (Fig. 3, compare $A$ and $C$; Fig. 4, compare $A$ and $E$ ). BrdU-immunoreactive nuclei increase sixfold in FGF2-treated cultures versus controls (Fig. 4, compare $C$ and G) (Vaccarino et al., 1995). At later stages in culture, trophic effects of FGF2 are also observed, primarily an increase in cell body size and length of processes (Vaccarino et al., 1995), although these effects have not been systematically analyzed.

To investigate whether FGF2 alters gene expression in precursor cells, we studied the effect of FGF2 on Otx2. Primary culture of cells from E12.5 and E13.5 rat telencephalon were treated with $10 \mathrm{ng} / \mathrm{ml}$ of FGF2 and harvested at 1, 3, 5, and 12 $\mathrm{d}$ in vitro (DIV). Otx2 expression was quantified by RNase protection assay (Fig. 2B). To correct for total cell number, Otx2 mRNA levels were normalized to the levels of GAPDH, an ubiquitously expressed gene. These normalized values were expressed as a percent of control. FGF2 treatment increased Otx2 expression by 2.45 - and a 1.8 -fold of control at 3 and 5 DIV, respectively. Ot $x 2$ mRNA levels were low in both control and FGF2-treated samples at 1 and 12 DIV. Low basal values at 1 DIV can be explained by a nonspecific, temporary shut down of mRNA synthesis at the beginning of culture. This is further illustrated by the broad dispersion of the values at 1 DIV. Low basal values for Otx2 at 12 DIV are consistent with the downregulation of this gene which has been described in vivo. There was no significant effect of FGF2 on Otx2 expression at 12 DIV even if we repeatedly treated the cells with FGF2 every $2 \mathrm{~d}$, or if we started the treatment beginning from $8 \mathrm{DIV}$.

To further characterize the effect of FGF2, cells were treated with increasing concentrations of FGF2 $(1,10,20$, and $40 \mathrm{ng} /$ $\mathrm{ml})$ at 5 DIV. Otx2 expression, normalized to levels of GAPDH, increased linearly between 10 and $20 \mathrm{ng} / \mathrm{ml}$, and started to reach a plateau at $40 \mathrm{ng} / \mathrm{ml}$ (eightfold stimulation) (Fig. 5). In contrast, in cells treated in parallel with increasing doses of NGF $(1,50$, and $100 \mathrm{ng} / \mathrm{ml}$ ), only a twofold increase of $O t x 2$ expression was observed, irrespective of the dose of NGF used (Fig. 5). These data suggest that FGF2 specifically increases the level of Otx2 mRNA relative to the total cellular RNA and/or that the proportion of Otx2-expressing cells relative to the total number of cells is increased.

\section{FGF2 increases the number of progenitor cells expressing} $\mathrm{Otx} 2$ and the expression of $\mathrm{Otx} 2$ within these cells

To investigate whether FGF2 increases the amount of Otx2 mRNA per cell or the number of cells expressing $O t \times 2$, we carried out in situ hybridization experiments. The preferential localization of $O: \times 2$ in precursor cells suggests that the FGF2mediated increase in $O t x 2$ expression may occur at early stages of development. Therefore, we compared the effect of FGF2 treatment on Otx2 expression in primary cultures obtained from E11.5, E12.5, and E13.5 telencephalon treated with $20 \mathrm{ng} / \mathrm{ml}$ of FGF2 and harvested at 5 DIV. In control samples (Fig. 6, upper panels), irrespectively of the age tested, the majority of Otx2labeled cells had low levels of labeling and only a few were darkly stained. In contrast, in samples treated with FGF2, the amount of $O t x 2$ mRNA per cell as well as the number of cells expressing $O t x 2$ were greatly increased (Fig. 6, lower panels). The extent of this increase was dependent on the age of the animals from which the cultures were prepared. FGF2 elicited a stronger increase in $O t x 2$ expression in cultures from E11.5 telencephalon (Fig. 6A,D) compared to cultures prepared from E13.5 basal telencephalon (Fig. 6B,E). Note that FGF2 had little 

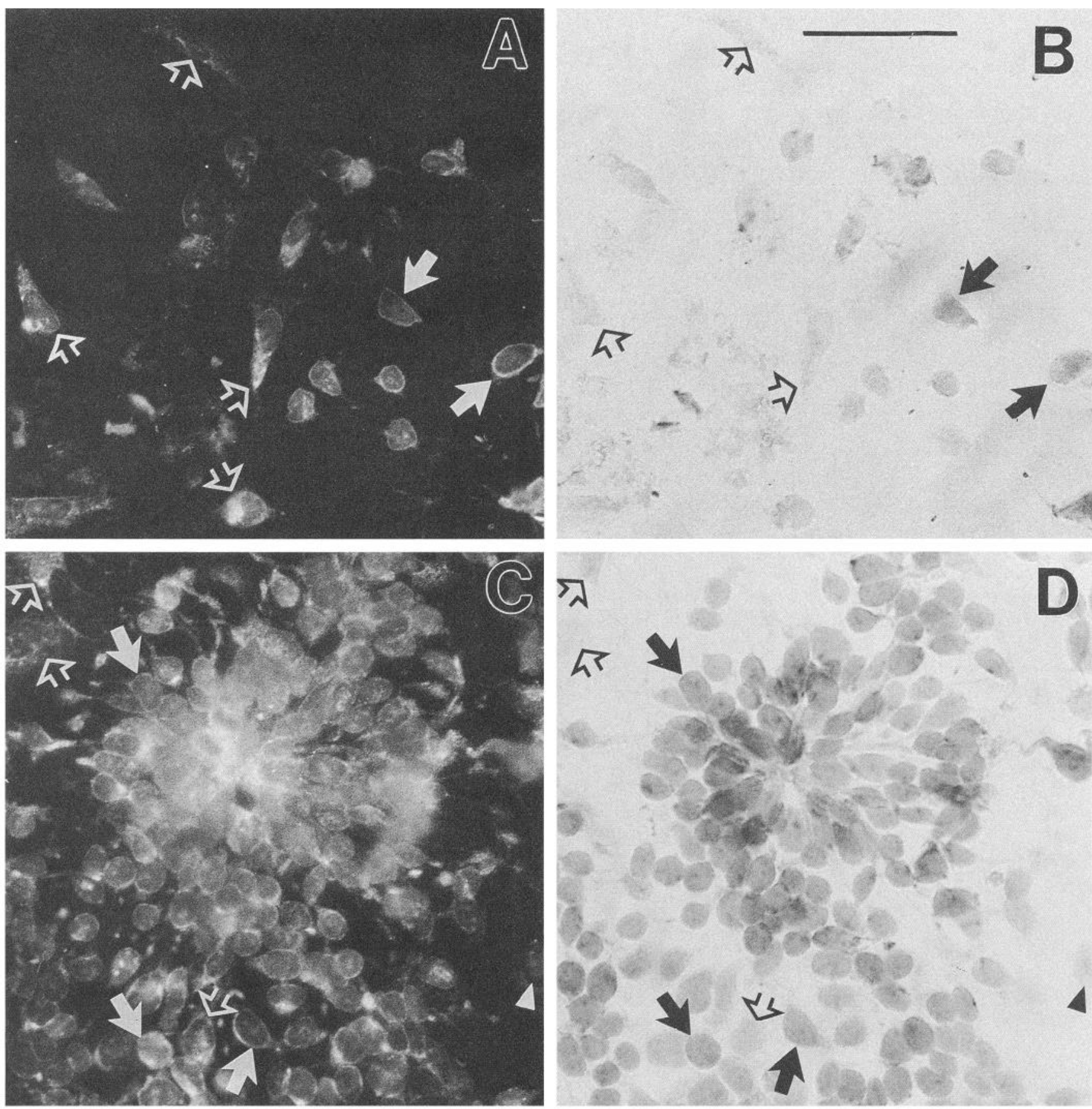

Figure 3. FGF2 increases the number of Otx2-positive progenitor cells at E11.5. Primary cultures of E11.5 telencephalon were left untreated (upper panels) or treated with FGF2 $(20 \mathrm{ng} / \mathrm{ml})$ at $1 \mathrm{~d}$ in vitro (lower panels). Cultures were fixed at 5 DIV and in situ hybridization for Otx2 (B, $D$ ) with double immunocytochemistry for nestin $(A, C)$ was performed. Solid arrows indicate representative nestin-positive cells expressing $O t x 2$; open arrows indicate representative nestin-positive cells negative for Otx2; arrowheads indicate representative cells negative for both nestin and Otx2. Scale bar, $50 \mu \mathrm{m}$.

or no effect in cultures from E13.5 dorsal telencephalon (Fig. $6 C, F)$. RNase protection assays confirmed that $20 \mathrm{ng} / \mathrm{ml}$ of FGF2 elicited a 6.6-fold increase in $0 t x 2$ expression (normalized to GAPDH levels) in cultures of E12.5 telencephalon, but only a 2.5-fold increase in cultures from E13.5 telencephalon (Fig. 7). Thus, the stimulation of $O t x 2$ expression by FGF2 in vitro is maximal at earlier stages of development.

A quantification of stained and unstained cells in random fields of cultures from E13.5 basal telencephalon confirmed that, in FGF2-treated samples, the total number of $O t \times 2$-positive cells was greatly increased (Table 1). To determine whether the increase in the number of cells expressing Ot $x 2$ elicited by FGF2 is due to a proliferative action of FGF2 on $O t \times 2$-containing precursors, BrdU incorporation was carried out for $1 \mathrm{hr}$ in control or FGF2-treated cells; samples were then subjected to in situ hybridization for $O t \times 2$ coupled to BrdU immunostaining. It was 

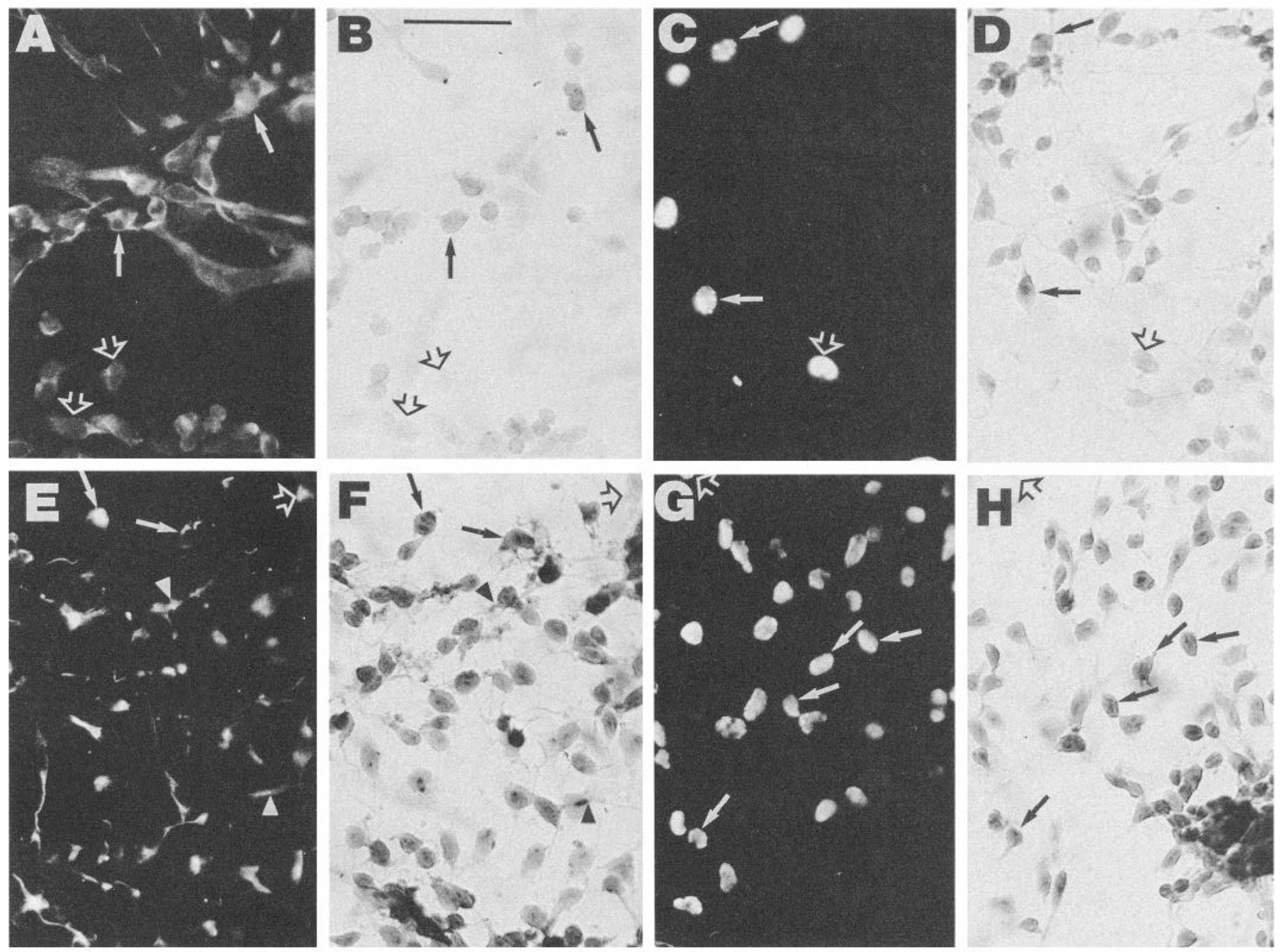

Figure 4. FGF2 increases the number of Otx2-positive precursor cells and their proliferation. Primary cultures of E13.5 basal telencephalon were left untreated (upper panels) or treated with FGF2 $(20 \mathrm{ng} / \mathrm{ml}$ ) at $1 \mathrm{~d}$ in vitro (lower panels). At $2 \mathrm{~d}$ in vitro, cells entering S phase were labeled with BrdU for $1 \mathrm{hr}$ and cells were fixed. In situ hybridization for $O t x 2(B, F, D, H)$ was coupled to double immunocytochemistry for either nestin $(A, E)$ or BrdU $(C, G)$. Solid arrows indicate representative nestin- or BrdU-positive cells expressing Otx2; arrowheads point to double-labeled processes; open arrows indicate representative nestin- or BrdU-positive cells negative for Otx2. Scale bar, $50 \mu \mathrm{M}$.

found that, in the control, only $12.4 \%(\mathrm{SEM}=6.4)$ of Otx2positive cells were double-labeled with BrdU, whereas in FGF2treated samples $22.2 \%$ (SEM $=9.7$ ) of $O t x 2$-positive cells were double-labeled with BrdU (compare panels $C, D$ with $G, H$ in Fig.

\section{Table 1. FGF2 treatment increases the number of cells expressing $O t x 2$}

Average cell number (SEM)

\begin{tabular}{|c|c|c|c|c|}
\hline \multirow[b]{2}{*}{ Treatment } & \multicolumn{4}{|c|}{ Average cell number (SEM) } \\
\hline & Otx 2 & Nestin & $\begin{array}{l}\% \text { of nestin } \\
\text { expressing } \\
\text { Otx2 }\end{array}$ & Total cells \\
\hline Control & $98.6(23)$ & $132(42)$ & $22.9(6.1)$ & $384(125)$ \\
\hline FGF2 & $194(24)^{*}$ & $208(28)$ & $32.6(5.5)^{*}$ & $550(53)$ \\
\hline
\end{tabular}

Primary cultures of E13.5 basal telencephalon were left untreated (control) or treated with FGF2 $(10 \mathrm{ng} / \mathrm{ml})$ at $1 \mathrm{~d}$ in vitro. Cells were fixed at $3 \mathrm{~d}$ in vitro. Otx2 was detected by in situ hybridization and nestin by immunofluorescence. Data represent the number of single or double labeled cells counted in 16 random fields for each culture, averaged from at least three separate experiments.

*Significantly different from control (Student's $t$ test, $p<0.05$ ).
4). Thus, FGF2 increases the number of Otx2-positive cells entering $S$ phase. As a result of this increased proliferation, the proportion of nestin-positive cells expressing $\mathrm{Ot} x 2$ increased after FGF2 treatment, both in cultures of E11.5 telencephalon (Fig. 3 ) and in cultures of E13.5 basal telencephalon (Fig. 4, panels $A, B$ and $E, F$ ). For basal telencephalon, these data are summarized in Table 1. Nestin-negative cells did not express Otx2, irrespective of FGF2 treatment. These results show that FGF2 does not induce $O t \times 2$ expression in a new set of cells, different from the nestin-positive precursor cells; the action of FGF2 in these cultures is to increases the absolute number and the proportion of nestin-positive precursor cells expressing $O t \times 2$. Furthermore, since the relative number of nestin-positive cells expressing $O t \times 2$ is increased by FGF2, these data indirectly suggest that FGF2 may change the developmental potential of the nestin-positive cells.

FGF2 treatment increases the expression of $\mathrm{Otx} 2$ in the basal, but not in the dorsal telencephalon

The differential expression of homeobox genes in basal and dorsal telencephalon indicates that these two regions may represent 


\section{$0 \quad 1 \quad 1020 \quad 40 \mathrm{ng} / \mathrm{ml} \mathrm{bFGF}$}
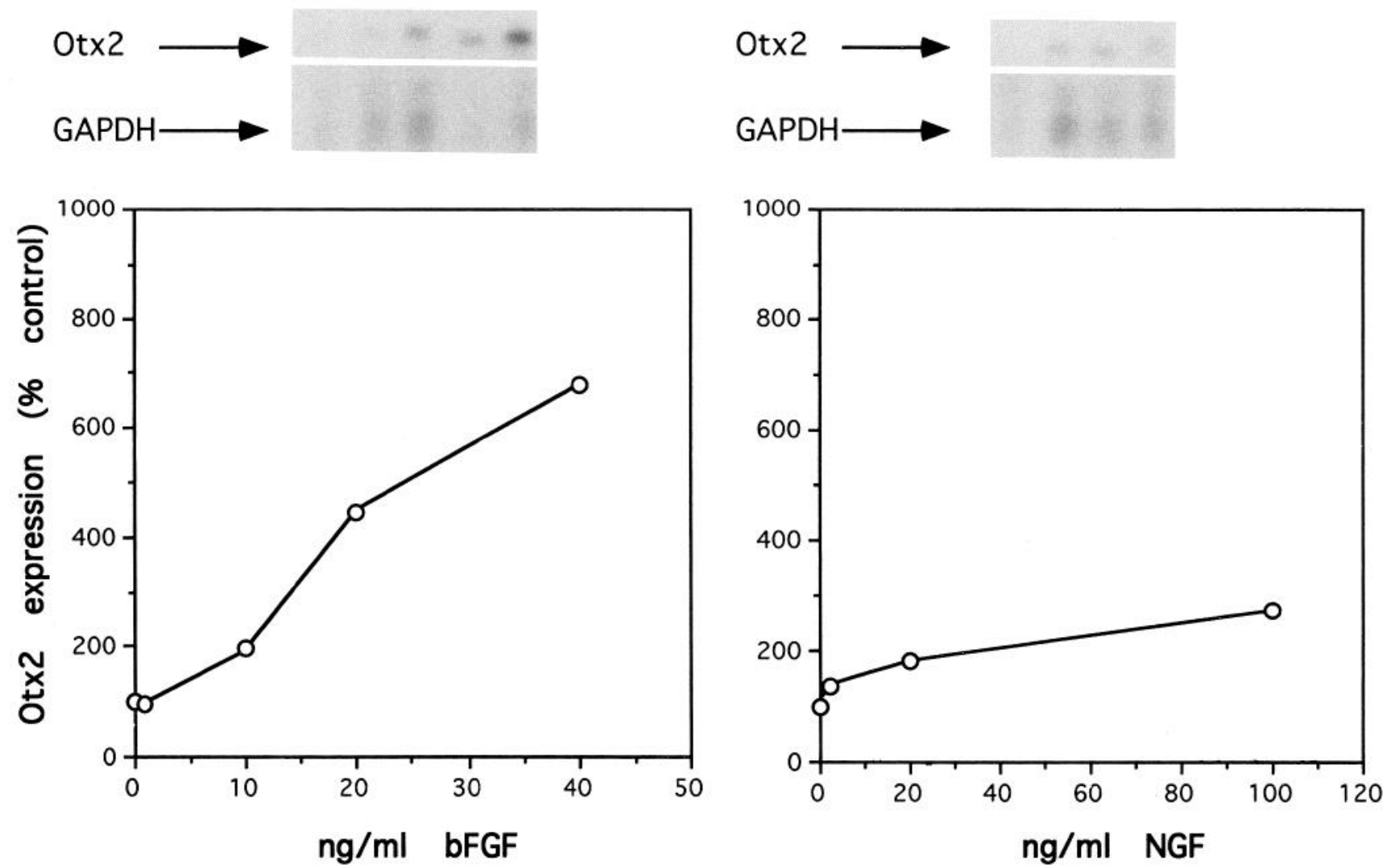

Figure 5. Treatment with FGF2 increases the expression of $O t \times 2$ in a specific and dose-dependent fashion. The expression of $O t \times 2$ was quantified by RNase protection assay in primary cultures of E12.5 rat telencephalon treated with the indicated concentrations of FGF2 (bFGF, left panels) or NGF (right panels) and harvested at 5 DIV. Upper panels show autoradiographic images and lower panels their densitometric quantification. Results are normalized by the level of GAPDH and expressed as percentage of control.

two distinct developmental units of the forebrain. To investigate whether the effect of FGF2 on homeobox gene expression is regionally regulated, we compared' the expression of EmxI, $D l x 1$, and $O t x 2$ in cultures from basal and dorsal telencephalon of E13.5 rat embryos (at this stage of development, a morphological distinction between these two regions is readily apparent). In cultures from basal telencephalon at 5 DIV, FGF2 induced a fivefold increase in the expression of Otx2 $(508 \pm 140 \%$ of control) (Fig. 8). This increase was statistically different both from the increase in the expression of Dlxl $(120 \pm 22 \%)$ and from the increase in the expression of GAPDH $(130 \pm 41 \%)$ (ANOVA, $F=7.41 ; p=0.01 ; N=4$ ). The FGF2-induced increase in $O t x 2$ expression was not followed by an increase in Dlxl expression later in the cultures, that is, at 7 and 12 DIV (data not shown). In the dorsal telencephalon, there was no increase in $O t x 2$ expression under FGF2 treatment, but rather a slight decrease, $(86 \pm 10 \%$ of control) which was not significantly different from the increase in GAPDH $(110 \pm 25 \%)$. Consistent with these data, in situ hybridization studies showed an increase in the number of cells expressing $0 t x 2$ in the basal telencephalon, but not in the dorsal telencephalon, after FGF2 treatment (Fig. 6; compare $B, E$ with $C, F$ ).

In contrast to Otx2, Emxl expression increased $(270 \pm 83 \%$ of control) in cultures from dorsal telencephalon after FGF2 treatment. This increase in Emxl expression was statistically different from the expression of $O t \times 2$ and GAPDH (ANOVA, $F=$ 7.17; $p=0.02 ; N=2$ ). The increase in Emxl in the dorsal telencephalon was not preceded by an increase in $0 t x 2$ expression at earlier stages (i.e., 3 DIV). In cultures obtained from whole telencephalon, we observed a twofold increase in the expression of Otx 2 (mean \pm SEM: $221 \pm 81 \%$ of control, $N=$ 2) (Fig. 8).

\section{Discussion}

Our first result is that telencephalic cells cultured in vitro maintain the pattern of homeobox gene expression characteristic of the region of origin. Our second finding is that $O t x 2$ is expressed by proliferative precursor cells in these cultures and that treatment with FGF2 increases the total number of Otx2-expressing cells, their relative proportion and the level to which they express Otx2. The temporal and regional regulation of the FGF2mediated increase in Otx2 mRNA suggests that this growth factor may be an endogenous stimulator of Otx2 expression.

Homeobox genes of the Otx, Emx, and Dlx subclasses are likely to play a role in the determination of telencephalic cell fates. The pattern of expression of these genes defines specific regions of the forebrain, such as the dorsal and basal telencephalon, as early as E10 in the mouse (Porteus et al., 1991; Price et al., 1991; Simeone et al., 1992a, 1994; Bulfone et al., 1993). The restricted anterior expression of $0 t x 2$ at early stages of head development appears to require a negative signal from the posterior mesendoderm and a positive signal from the anterior mesoderm (Ang et al., 1994). We suggest that, during early stages of neurogenesis, this positive signal might be a member of the 

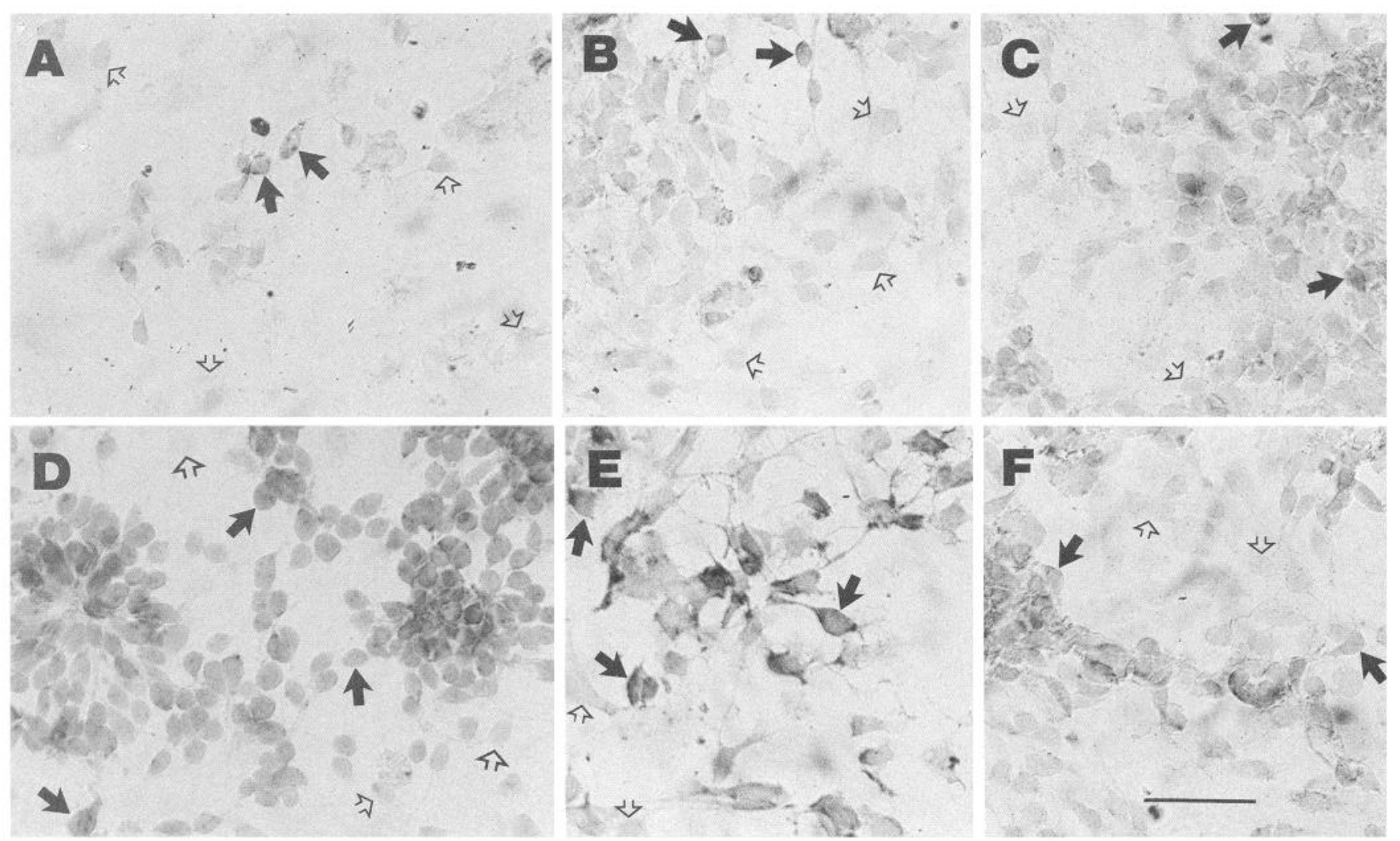

Figure 6. The FGF2-induced increase in Otx2 expression is strongest at earlier stages of development. Primary cultures of cells from E11.5 (A, $D$ ) and E13.5 rat telencephalon $(B, C, E, F)$ were left untreated (top panels) or treated with $20 \mathrm{ng} / \mathrm{ml}$ of FGF2 (bottom panels) and harvested at 5 DIV. Otx2 mRNA was detected by in situ hybridization. In cultures from E13.5 embryos FGF2 induces an increase in Otx2-positive cells in basal $(B, E)$ but not in dorsal $(C, F)$ telencephalon. Solid arrows indicate representative Otx2-positive cells; open arrows indicate background hybridization. Scale bar, $50 \mu \mathrm{M}$.

FGF family, since at least three FGF-related molecules are expressed, concomitantly to $O t x 2$, at early stages of the development of the prosencephalon (Tannahill et al., 1992; Nurcombe et al., 1993; Crossley and Martin, 1995). Our results suggest that both cell autonomous and non autonomous factors are operative in the regulation of homeobox gene expression during telencephalic development. We show that the in vivo pattern of expression of Dlx and Otx homeobox genes in the basal and dorsal telencephalon is maintained after cell dissociation and placement in the artificial culture environment. Our data also show that that factors present in the cellular environment may be essential for Otx2 expression.

\section{Telencephalic cells in primary cultures maintain their regional identity}

Our data indicate that, in dissociated primary cultures of basal and dorsal telencephalon obtained from an E13.5 rat brain, Otxl, $E m x 1, D l x 1, D l x 2$, and $D l x 5$ are expressed according to the regional pattern of expression found in vivo at an equivalent stage of development. Indeed, $D l x l, D l \times 2$, and $D l x 5$ are preferentially expressed in cultures from basal telencephalon and Emxl is expressed in cultures from dorsal telencephalon, consistent with data obtained by in situ hybridization (Simeone et al., 1992a,b; Porteus et al., 1991, 1994; Price et al., 1991). Otx1 and Otx2 are expressed in cultures from both basal and dorsal telencephalon. Although $O t x 2$ is absent from the mouse dorsal telencephalon by E12.5, this gene is expressed at high levels in the choroid plexus of the lateral ventricle and in the lateral septum of the rodent brain even in postnatal animals (Simeone et al., 1993; Frantz et al., 1994). Since we also detected Otx2 expression in explants of E14.5-E16.5 dorsal telencephalon immediately after dissection from the embryo, we think that the $O t \times 2$ expression observed in dorsal telencephalic cultures may derive from the choroid plexus, and does not imply a deregulation of $0 t x 2$ expression in vitro. Indeed, the fact that the expression of Otx2 detected in cultures from dorsal telencephalon was not induced by FGF2 (Fig. $8 B$ ) suggests that this expression is not neuronal. The observation that the regional pattern of homeobox gene expression is maintained in culture suggest that, by E13.5, telencephalic cells are committed to their region fate. Similar findings have been shown in Xenopus, where the regional pattern of expression of three members of the $D l x$ family is maintained in ectodermal explants, independently of mesoderm-inducing signals (Papalopulu and Kintner, 1993). Furthermore, Lemaire and Gurdon have shown that, in Xenopus, the spatial pattern of expression of Goosecoid and Xwnt-8 along the dorso-ventral axis is the same in intact and dissociated early gastrulas, suggesting that both cell autonomous and induction-dependent phenomena are involved in mesoderm patterning (Lemaire and Gurdon, 1994).

\section{FGF2 stimulates the expression of Otx2 in telencephalic progenitor cells}

We further demonstrated that the in vitro treatment of cell taken from an E11.5-13.5 rat telencephalon with FGF2 leads to an increase in the expression of $O t x 2$, but not of Dlxl. We inves- 

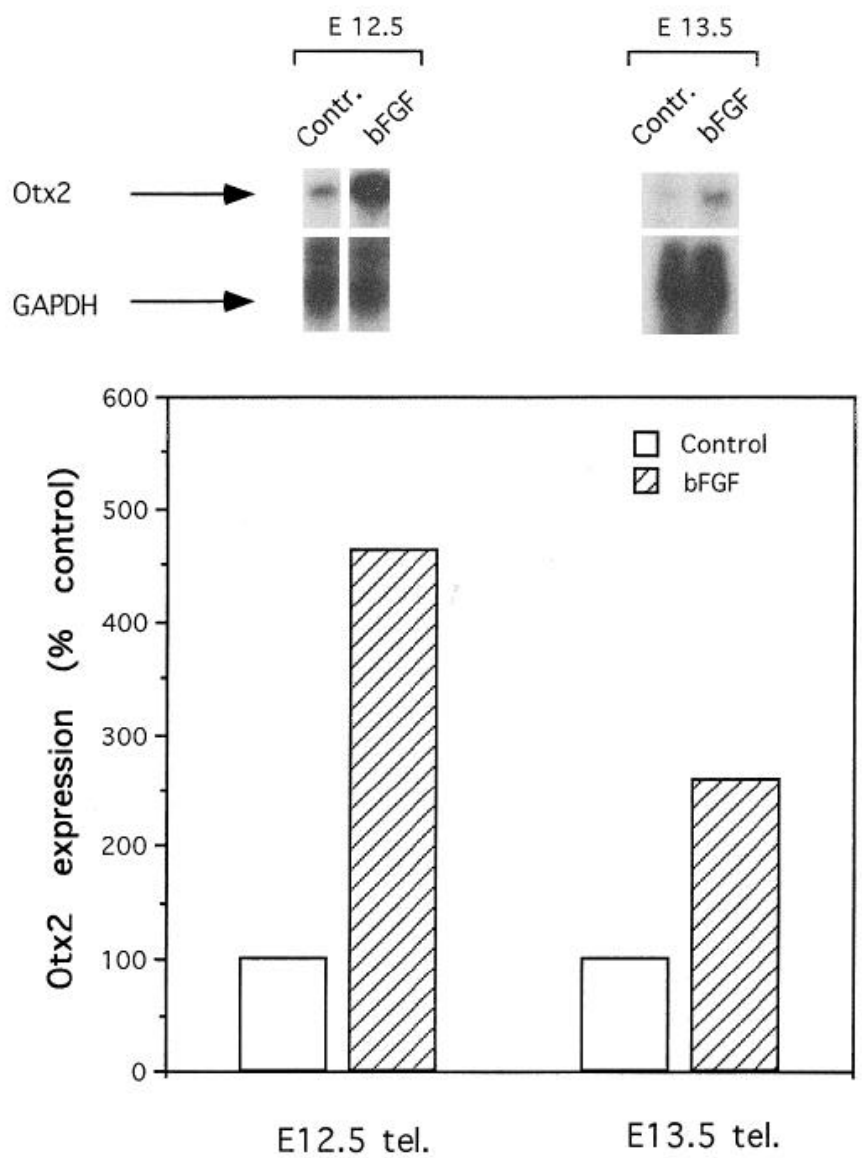

Figure 7. The FGF2-induced increase in Otx2 expression is stronger in primary cultures from E12.5 than from E13.5 rat telencephalon. Quantification by RNase protection assay of Otx 2 expression in primary cultures of E12.5 and E13.5 rat telencephalon treated with $20 \mathrm{ng} / \mathrm{ml}$ of FGF2 and harvested at 5 DIV. Upper panels show autoradiographic images and lower panels their densitometric quantification. Results are normalized by the level of GAPDH and expressed as percentage of control.

tigated the identity of the Otx2-containing cells by in situ hybridization coupled with immunocytochemistry. Otx2 mRNA was expressed by nestin-positive cells, but not by MAP2-positive neurons, suggesting that Otx2-expressing cells are precursor cells of the mammalian telencephalon. BrdU labeling experiments in cultures of basal telencephalon from E13.5 embryos showed that approximately $50 \%$ of the Otx2-expressing cells are proliferative and $50 \%$ are quiescent or perhaps have exited the cell cycle, since they are not labeled by a $20 \mathrm{hr}$ BrdU pulse. Thus, it may be hypothesized that, at this stage of development, Ot $x 2$ is expressed by proliferative cells, continues to be expressed transiently in postmitotic cells, and is down-regulated in MAP2-positive, terminally differentiated cells. This is consistent with the localization of Otx2 in the ventricular layer by in situ hybridization (Simeone et al., 1993). Conversely, the majority of Dlxl-containing cells are postmitotic neuronal cells.

After FGF2 treatment of primary cultures of rat telencephalon, a dramatic stimulation of $O t x 2$ expression was observed, due both to an increase in the relative number of precursor cells expressing $O t x 2$ and to the induction of $O t x 2$ expression within these cells. This increased number of $O t x 2$-positive cells may be attributed to either a stimulation of their proliferation, or to a recruitment of new progenitors into an Otx2-expressing pool.
Since there is an increased number of $O t \times 2$-positive cells incorporating BrdU in FGF2-treated cultures versus controls, it is likely that FGF2 acts as a mitogen for Otx2-expressing cells.

One interpretation of these data is that the effect of FGF2 on proliferation and on $O t \times 2$ expression are interdependent and perhaps that the $O t \times 2$ gene product has a role in the proliferative action of FGF2. However, it is not clear whether the proliferative effect of FGF2 is restricted to the Otx2-positive cells, and furthermore, Otx 2 is expressed by proliferative cells as well as by cells that appear to be relatively quiescent. A more likely interpretation is that FGF2 regulates Otx2 expression and proliferation by two distinct and independent actions. This hypothesis predicts that the increased expression of the $O t \times 2$ gene product by progenitor cells after FGF2 treatment is not related to the increase in cell proliferation but to other effects of FGF2, such as the regulation of differentiation or of cell fate.

Otx 2 expression in vivo is maximal at E10-E11 and is downregulated in the mouse dorsal telencephalon by E12.5, persisting at a lower level in the basal telencephalon until E15-E16. The FGF2-mediated increase in Otx2 expression in vitro is stronger in cultures taken from E11.5 embryos compared to cultures taken from E13.5 embryos. These data suggest that FGF2 does not act by preventing the normal down regulation of Otx2 during development.

Otx 2 is highly expressed by cells of the ventricular zone at early stages of neurogenesis in vivo. By contrast, in primary culture, a relatively low number of progenitor cells express Otx2 under basal conditions, suggesting that these cells lack a secreted extracellular component which induces Otx2 expression in vivo. Furthermore, our observation that $O t x 2$ expression is lower at 1 $\mathrm{d}$ in vitro futher supports the idea that an extracellular component must be secreted in the culture environment for $0 t x 2$ expression to occur. In agreement with this interpretation, signals provided by the anterior edge of the mesoderm are necessary for the induction and the stabilization of early $O t x 2$ expression (Ang et al., 1994). Thus, the striking increase in the number of Otx2-containing cells after FGF2 treatment, and the fact that this FGF2-mediated increase correlates with the temporal pattern of expression in vivo, suggest an important role of endogenous FGF2 in the stimulation of Otx2 expression. The expression of FGF2 and its receptors overlap spatially and temporally with the expression of Otx2 (Powell et al., 1991a; Giordano et al., 1992; Nurcombe et al., 1993; Weise et al., 1993). The FGF-R1, FGFR2, and FGF-R3 have been localized within the germinal ventricular layer of the telencephalon at early stages of development (Heuer et al., 1990; Orr-Urtreger et al., 1991; Wanaka et al., 1991; Peters et al., 1993). Since Otx2 is also expressed within this layer, Otx2-containing cells may express FGF receptors.

\section{The stimulation of Otx2 expression by $F G F 2$ is regionally regulated}

In cultures prepared from E13.5 rat embryos, FGF2 increases Otx2 expression in the basal, but not dorsal, telencephalon. Conversely, it appears that cells of the dorsal telencephalon respond to FGF2 by upregulating Emxl expression. However, because of the low number of samples in which levels of Emxl were examined, a conclusive statement cannot be made regarding EmxI.

One interpretation of this dissociation of FGF2's effect is that, by E13.5, precursor cells of the dorsal telencephalon have lost their ability to express Otx2 in response to FGF2. Consistent with this hypothesis is the observation that $O t x 2$ expression in the dorsal telencephalon in vivo is normally downregulated by 


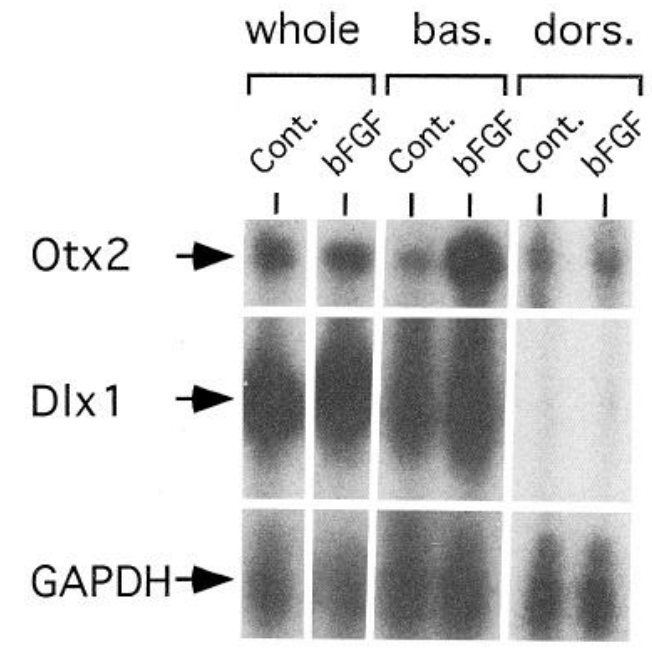

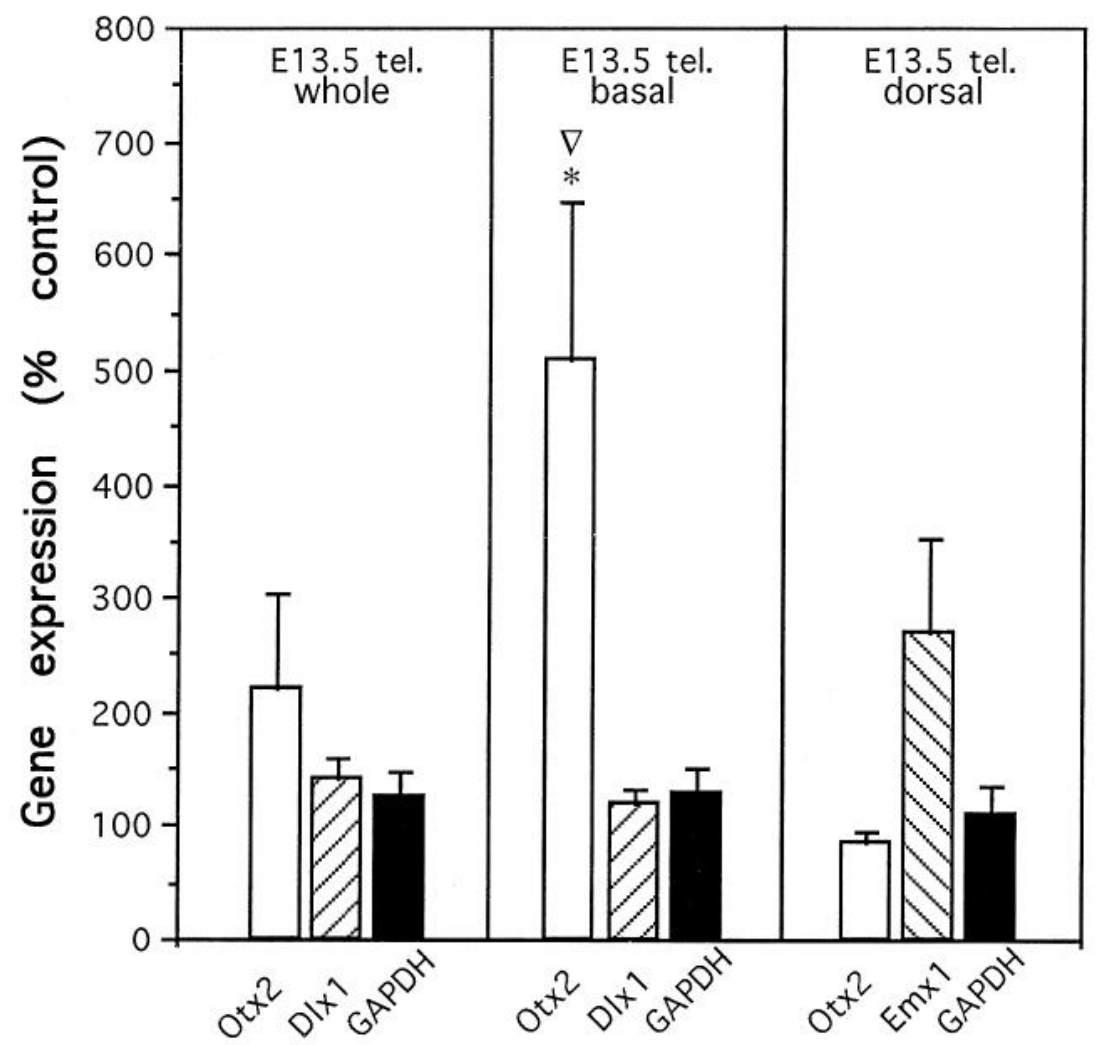

Figure 8. The FGF2-induced increase in $O t \times 2$ expression is observed in basal, but not in dorsal telencephalon. The expression of $O t \times 2, E m x 1$, and $D l x l$ was assessed by RNase protection assay in primary cultures of E13.5 whole, basal or dorsal rat telencephalon treated with $20 \mathrm{ng} / \mathrm{ml}$ of FGF2, and harvested at 5 DIV. $A$, Autoradiographic image of representative experiments. $B$, The effect of FGF2 treatment on each gene is expressed as a percentage of control. Mean and SEMs were obtained from two to four independent experiments. In the basal telencephalon, the effect of FGF2 treatment on Otx2 expression was significantly different from the effect on GAPDH $(*)$ and Dlx1 $(\diamond)$ (one-tail ANOVA, $F=7.41 ; p=0.01$; $N=4)$. The FGF2-induced increase in Emxl expression observed in the dorsal telencephalon also reached statistical significance $(F=7.17 ; p=0.02 ; N=$ 2). this stage of development (Simeone et al., 1993; Frantz et al., 1994). A similar phenomenon has been described in cultures of ectodermal cells from Xenopus gastrula. In this system, the induction of neural lineages by FGF2 is progressively lost in cells prepared from gastrula of increasing age. This loss occurs first for cells from the basal ectoderm and is followed later by cells from the dorsal ectoderm (Kengaku and Okamoto, 1993), and closely parallels the loss of neural competence observed in vivo.

An alternative interpretation is that FGF2 increases $O t \times 2$ ex- pression through a particular receptor type which is absent from cells of the dorsal telencephalon. The differential response of dorsal and basal telencephalic cells to FGF2 may be due to a differential distribution of FGF receptor subtypes on their membranes secondary to their regulation by different FGF-related members. For example, FGF-7 is selectively expressed at E14.5 in the ventricular layer of the ganglionic eminence, the parietal and the frontal cortex, whereas Int 2 and FGF5 are broadly expressed in germinative layers from earlier stages (E9) (Wilkin- 
son et al., 1987; Giordano et al., 1992; Mason et al., 1994). It remains to be determined whether Otx2-containing cells also express a particular FGF2 receptor subtype which is differentially distributed in the telencephalon. In summary, our findings suggest that the competence of progenitors to respond to FGF2 is related to the acquisition of a regional identity in the mammalian telencephalon.

\section{Role of Otx 2 in neurogenesis}

If Otx2 plays a role in the regulation of cell fate during early neurogenesis, is this a general role or is it limited to particular cell lineages? Since both neuronal and glial progenitors express nestin (Gallo and Armstrong, 1995), the localization of Otx2 in nestin-positive cells does not answer the question as to whether Otx 2 expression is restricted to neurons or glia. However, several indirect observations support the hypothesis that $O t x 2$ is expressed in neuronal, rather than in glial progenitors. In vivo, the early pattern of expression of $O t x 2$ in the ventricular zone of the cerebral cortex and ganglionic eminence correlates with the period of neuronal proliferation, since the peak of glial proliferation occurs after birth (Bayer and Altman, 1991; Cameron and Rakic, 1991). Similarly, in the primary culture model used in this study, the proliferation of neuronal precursors in basal and FGF2-stimulated conditions peaks between 2 and 5 DIV, whereas the proliferation of glial precursors peaks at 10-12 DIV (Vaccarino et al., 1995). FGF2 increases Otx2 expression at 3 and 5 DIV, but not at 7 and $12 \mathrm{DIV}$, suggesting that $0 t \times 2$ has a role in the FCF2-mediated proliferation of neuronal progenitors, but not of glial progenitors.

We have previously shown that FGF2 increases the proliferation of precursor cells of glutamate-containing neurons, without significantly affecting precursors of GABA-containing neurons (Vaccarino et al., 1995). The concomitant effect of FGF2 on Otx2 expression suggests that, at this stage of development, Otx2 may be expressed by a subclass of progenitor cells committed, at least in part, to a glutamate neuron fate. Retrovirus-mediated lineage analysis in the mammalian telencephalon has shown that glutamate (pyramidal) and GABA (nonpyramidal) neurons arise from distinct classes of progenitors whose lineages diverge before E15 (Luskin et al., 1993; Mione et al., 1994). The commitment of neuronal progenitors to these different lineages might be regulated by extraccllular cues. Whether the sclective cffect of FGF2 on the development of the glutamate lineage observed in these cultures is related to the effect of FGF2 on Otx2 expression remains to be demonstrated. It would be interesting to study the lineage of Otx2-expressing cells in order to clarify whether glutamate-containing neurons are part of their descendants.

\section{References}

Ang S-L, Conlon RA, Jin O, Rossant J (1994) Positive and negative signals from mesoderm regulate the expression of mouse Otx2 in ectoderm explants. Development 120:2979-2989.

Ausubel FM, Brent R, Kingston RE, Moore DD, Seidman JG, Smith JA, Struhl K (1989) Current protocols in molecular biology. New York: Greene/Wiley-Interscience.

Bayer SA, Altman J (1991) Neocortical development. New York: Raven.

Binder LI, Frankfurter A and Rebhun LI (1986) Differential localization of MAP-2 and tau in mammalian neurons in situ. Ann NY Acad Sci 466:145-166.

Bulfone A, Puelles I, Porteus MH, Frohman MA, Martin GR, Rubenstein JL (1993) Spatially restricted expression of Dlx-1, Dlx-2 (Tes1 ), Gbx-2, and Wnt-3 in the embryonic day 12.5 mouse forebrain defines potential transverse and longitudinal segmental boundaries. J Neurosci 13:3155-3172.

Cameron RS, Rakic P (1991) Glial cell lineage in the cerebral cortex: a review and synthesis. Glia 4:124-137.

Campos-Ortega JA (1993) Mechanisms of early neurogenesis in Drosophila melanogaster [Review]. J Neurobiol 24:1305-1327.

Chisaka O, Capecchi MR (1991) Regionally restricted developmental defects resulting from targeted disruption of the mouse homeobox gene Hox 1.5. Nature 350:473-479.

Chisaka O, Musci TS, Capecchi MR (1992) Developmental defects of the ear, cranial nerves and hindbrain resulting from targeted disruption of the mouse homeobox gene Hox-1.6. Nature 355:516-520.

Cho KW, De Robertis EM (1990) Differential activation of Xenopus homeo box genes by mesoderm-inducing growth factors and retinoic acid. Genes Dev 4:1910-1916.

Crossley PH, Martin GR (1995) The mouse Fgf8 gene encodes a family of polypeptides and is expressed in regions that direct outgrowth and patterning in the developing embyo. Development 121:439-451.

Dolle P, Lufkin T, Krumlauf R, Mark M, Duboule D, Chambon P (1993) Local alterations of Krox-20 and Hox gene expression in the hindbrain suggest lack of rhombomeres 4 and 5 in homozygote null Hoxa-1 (Hox-1.6) mutant embryos. Proc Natl Acad Sci USA 90: $7666-7670$.

Ericson J, Thor S, Edlund S, Jessel TM, Yamada T (1992) Early stages of motor neuron differentiation revealed by expression of homeobox gene Islet-1. Science 256:1555-1560.

Frantz GD, Weimann JM, Levin ME, McConnell SK (1994) Otx 1 and Otx2 define layers and regions in developing cerebral cortex and cerebellum. J Neurosci 14:5725-5740.

Gallo V, Armstrong RC (1995) Developmental and growth factor-induced regulation of nestin in oligodendrocyte lineage cells. J Neurosci 15:394-406.

Gensburger C, Labourdette G, Sensenbrenner M (1987) Brain basic fibroblast growth factor stimulates the proliferation of rat neuronal precursor cells in vitro. FEBS Lett 217:1-5.

Ghysen A, Dambly-Chaudiere C, Jan LY, Jan YN (1993) Cell interactions and gene interactions in peripheral neurogenesis [Review]. Genes Dev 7:723-733.

Giordano S, Sherman L, Lyman W, Morrison R (1992) Multiple molecular weight forms of basic fibroblast growth factor are developmentally regulated in the central nervous system. Dev Biol 152:293303.

Guthrie S, Lumsden A (1992) Motor neuron pathfinding following rhombomere reversals in the chick embryo hindbrain. Development 114:663-673.

Guthrie S, Muchamore I, Kuroiwa A, Marshall H, Krumlauf R, Lumsden A (1992) Neuroectodermal autonomy of Hox-2.9 expression revealed by rhombomere transpositions. Nature 356:157-159.

Heuer JG, von Bartheld CS, Kinoshita Y, Evers PC, Bothwell M (1990) Alternating phases of FGF receptor and NGF receptor expression in the developing chicken nervous system. Neuron 5:283-296.

Kengaku M, Okamoto H (1993) Basic fibroblast growth factor induces differentiation of neural tube and neural crest lineages of cultured ectoderm cells from Xenopus gastrula. Development 119:1067-1078.

Kessel M (1993) Reversal of axonal pathways from rhombomere 3 correlates with extra Hox expression domains. Neuron 10:379-393.

Lawrence PA, Morata G (1994) Homeobox genes: their function in Drosophila segmentation and pattern formation. Cell 78:181-189.

Lemaire P, Gurdon JB (1994) A role for cytoplasmic determinants in mesoderm patterning; cell-autonomous activation of the goosecoid and Xwnt-8 genes along the dorsoventral axis of early Xenopus embryos. Development 120:1191-1199.

Lendahl U, Zimmerman LB, McKay RDG (1990) CNS stem cells express a new class of intermediate filament protein. Cell 60:585-595.

Luskin MB, Parnavelas JG, Barfield JA (1993) Neurons, astrocytes, and oligodendrocytes of the rat cerebral cortex originate from separate progenitor cells: an ultrastructural analysis of clonally related cells. J Neurosci 13:1730-1750.

Marshall H, Nonchev S, Sham MH, Muchamore I, Lumsden A, Krumlauf $R$ (1992) Retinoic acid alters hindbrain Hox code and induces transformation of rhombomeres $2 / 3$ into a $4 / 5$ identity. Nature 360 : $737-741$.

Mason I J, Fuller-Pace F, Smith R, Dickson C (1994) FGF-7 (keratinocyte growth factor) expression during mouse development suggests 
roles in myogenesis, forebrain regionalization and epithelial-mesenchymal interactions. Mech Dev 45:15-30.

McConnell SK (1991) The generation of neuronal diversity in the central nervous system [Review]. Annu Rev Neurosci 14:269-300.

McGinnis W, Krumlauf R (1992) Homeobox genes and axial patterning [Review]. Cell 68:283-302.

Mione MC, Danevic C, Boardman P, Harris B, Parnavelas JG (1994) Lineage analysis reveals neurotransmitter (GABA or glutamate) but not calcium-binding protein homogeneity in clonally related cortical neurons. J Neurosci 14:107-123.

Murphy M, Drago J, Bartlett PF (1990) Fibroblast growth factor stimulates the proliferation and differentiation of neural precursor cells in vitro. J Neurosci Res 25:463-475.

Niswander L, Martin GR (1993) FGF-4 regulates expression of Evx-1 in the developing mouse limb. Development 119:287-294.

Nurcombe V, Ford MD, Wildschut JA, Bartlett PF (1993) Developmental regulation of neural response to FGF-1 and FGF-2 by heparan sulfate proteoglycan. Science 260:103-106.

Orr-Urtreger A, Givol D, Yayon A, Yarden Y, Lonai P (1991) Developmental expression of two murine fibroblast growth factor receptors, flg and bek. Development 113:1419-1434.

Papalopulu N, Kintner C (1993) Xenopus Distal-less related homeobox genes are expressed in the developing forebrain and are induced by planar signals. Development 117:961-975.

Peters K, Ornitz D, Werner S, Williams L (1993) Unique expression pattern of the FGF Receptor 3 gene during mouse organogenesis. Dev Biol 155:423-430.

Porteus MH, Bulfone A, Ciaranello RD, Rubenstein JL (1991) A par tial cDNA sequence of the Dlx-2 cDNA. Neuron 9:187.

Porteus MH, Bulfone A, Liu JK, Puelles L, Lo LC, Rubenstein JLR (1994) DLX-2, MASH-1, and MAP2 expression and bromodeoxyuridine incorporation define molecularly distinct cell populations in the embryonic mouse forebrain. J Neurosci 14:6370-6383.

Powell PP, Finklestein SP, Dionne CA, Jaye M, Klagsbrun M (1991a) Temporal, differential and regional expression of mRNA for basic fibroblast growth factor in the developing and adult rat brain. Brain Res Mol Brain Res 11:71-77.

Powell PP, Finklestein SP, Dionne CA, Jaye M, Klagsbrun M (1991b) Temporal, differential and regional expression of $m R N \wedge$ for basic fibroblast growth factor in the developing and adult rat brain. Dev Brain Res 62:71-77.

Price M, Lemaistre M, Pischetola M, Di Lauro R, Duboule D (1991) A mouse gene related to Distal-less shows a restricted expression in the developing forebrain. Nature 351:748-751.

Ray J, Peterson DA, Schinstine M, Gage FH (1994) Proliferation, differentiation, and long-term culture of primary hippocampal neurons. Proc Natl Acad Sci USA 90:3602-3606.

Ruiz i Altaba A, Melton DA (1989) Interaction between peptide growth factors and homoeobox genes in the establishment of antero-posterior polarity in frog embryos. Nature 341:33-38.

Simeone A, Acampora D, Gulisano M, Stornaiuolo A, Boncinelli E (1992a) Nested expression domains of four homeobox genes in developing rostral brain. Nature 358:687-690.

Simeone A, Gulisano M, Acampora D, Stornaiuolo A, Rambaldi M Boncinelli E (1992b) Two vertebrate homeobox genes related to the Drosophila empty spiracles gene are expressed in the embryonic cerebral cortex. EMBO J 11:2541 2550.

Simeone A, Acampora D, Mallamaci A, Stornaiuolo A, D'Apice MR, Nigro V, Boncinelli E (1993) A vertebrate gene related to orthodenticle contains a homeodomain of the bicoid class and demarcates anterior neuroectoderm in the gastrulating mouse embryo. EMBO J $12: 2735-2747$.

Simeone A, Acampora D, Pannese M, D'Esposito M, Stornaiuolo A, Gulisano M, Mallamaci A, Kastury K, Druck T, Huebner $K$, et al (1994) Cloning and characterization of two members of the vertebrate Dlx gene family. Proc Natl Acad Sci USA 91:2250-2254.

Takahashi T, Nowakowski RS, Caviness VS Jr (1994) Mode of cell proliferation in the developing mouse neocortex. Proc Natl Acad Sci USA 91:373-379.

Tannahill D, Isaacs HV, Close MJ, Peters G, Slack JM (1992) Developmental expression of the Xenopus int-2 (FGF-3) gene: activation by mesodermal and neural induction. Development 115:695-702.

Vaccarino FM, Alho H, Santi MR, Guidotti A (1987) Coexistence of GABA receptors and GABA-modulin in primary cultures of rat cerebellar granule cells. J Neurosci 7:65-76.

Vaccarino FM, Schwartz ML, Hartigan D, Leckman JF (1995) Effect of basic fibroblast growth factor on the genesis of excitatory and inhibitory neurons in primary cultures of cells from the mammalian telencephalon. Cereb Cortex 1:1047-3211.

von Dassow G, Schmidt JE, Kimelman D (1993) Induction of the Xenopus organizer: expression and regulation of Xnot, a novel FGF and activin-regulated homeo box gene. Genes Dev 7:355-366.

Wahle P, Beckh S (1992) A method of in situ hybridization combined with immunocytochemistry, histochemistry, and tract tracing to characterize the mRNA expressing cell types in heterogeneous neuronal populations. J Neurosci Methods 41:153-166.

Walicke P, Cowan WM, Ueno N, Baird A, Guillemin R (1986) Fibroblast growth factor promotes survival of dissociated hippocampal neurons and enhances neurite extension. Proc Natl Acad Sci USA 83:3012-3016.

Wanaka A, Milbrandt J, Johnson EM Jr (1991) Expression of FGF receptor gene in rat development. Development 111:455-468.

Weise B, Janet T, Grothe C (1993) Localization of bFGF and FGFreceptor in the developing nervous system of the embryonic and newborn rat. J Neurosci Res 34:442-453.

Wilkinson DG, Bailes JA, McMahon AP (1987) Expression of the proto-oncogene int- 1 is restricted to specific neural cells in the developing mouse embryo. Cell 50:79-88. 